\title{
Dimethylamine and ammonia measurements with ion chromatography during the CLOUD4 campaign
}

\author{
A. P. Praplan, F. Bianchi, J. Dommen, and U. Baltensperger \\ Laboratory of Atmospheric Chemistry, Paul Scherrer Institute, Villigen PSI, Switzerland \\ Correspondence to: J. Dommen (josef.dommen@psi.ch) \\ Received: 3 February 2012 - Published in Atmos. Meas. Tech. Discuss.: 23 March 2012 \\ Revised: 11 August 2012 - Accepted: 13 August 2012 - Published: 7 September 2012
}

\begin{abstract}
The CLOUD project investigates the influence of galactic cosmic rays on the nucleation of new particles in an environmental chamber at CERN. Dimethylamine (DMA) was injected intentionally into the CLOUD chamber to reach atmospherically relevant levels away from sources (up to 100 pptv) in order to study its effect on nucleation with sulphuric acid and water at $278 \mathrm{~K}$. Quantification of DMA and also background ammonia $\left(\mathrm{NH}_{3}\right)$ was performed with ion chromatography (IC). The IC method used together with the sampling line developed for CLOUD in order to measure $\mathrm{NH}_{3}$ and DMA at low pptv levels is described; the overall sampling efficiency of the method is discussed; and, finally, mixing ratios of $\mathrm{NH}_{3}$ and DMA measured during CLOUD4 are reported.
\end{abstract}

\section{Introduction}

The CLOUD project investigates the influence of galactic cosmic rays (GCR) on the climate through their effect on cloud properties (Kirkby, 2007). A key process of these studies is the nucleation of new particles in the atmosphere from gaseous precursors and their growth to detectable sizes (diameter $>3 \mathrm{~nm}$ ) (Kulmala et al., 2004; Hirsikko et al., 2011). These particles can eventually grow to cloud condensation nuclei $(\mathrm{CCN})$ and influence indirectly the Earth's climate by modifying cloud properties. Recently published CLOUD data (Kirkby et al., 2011) on the ternary sulphuric acid $\left(\mathrm{H}_{2} \mathrm{SO}_{4}\right)$ /water $\left(\mathrm{H}_{2} \mathrm{O}\right) /$ ammonia $\left(\mathrm{NH}_{3}\right)$ nucleation system (Coffman and Hegg, 1995; Korhonen et al., 1999; Kulmala et al., 2000) demonstrated that $\mathrm{NH}_{3}$ (at a 100 pptv-level or less) increases nucleation rates by a factor higher than 100 to 1000 over the binary $\left(\mathrm{H}_{2} \mathrm{SO}_{4} / \mathrm{H}_{2} \mathrm{O}\right)$ system. However,
$\mathrm{NH}_{3}$ was still not sufficient to explain the nucleation rates observed under typical tropospheric conditions $\left(10^{6}-10^{7} \mathrm{~cm}^{-3}\right.$ $\mathrm{H}_{2} \mathrm{SO}_{4}$ ).

Because amines possess structural similarities with $\mathrm{NH}_{3}$ where one, two or all three hydrogen atoms are replaced by organic moieties $\left(\mathrm{RNH}_{2}, \mathrm{R}_{2} \mathrm{NH}\right.$ or $\left.\mathrm{R}_{3} \mathrm{~N}\right)$, their effect on secondary organic aerosol formation is increasingly subject of investigation. Murphy et al. (2007) showed that amines can form secondary organic aerosol (SOA), by acting as bases and neutralising acids present in the gas phase similar to $\mathrm{NH}_{3}$, but also by participating in gas phase chemistry initiated by hydroxyl radicals $\left(\mathrm{OH}^{*}\right)$ or ozone $\left(\mathrm{O}_{3}\right)$ to form low volatility products (see also Tuazon et al., 1994). Furthermore, a recent computational study suggests that amines are even more strongly bound to $\mathrm{H}_{2} \mathrm{SO}_{4}$ molecules than $\mathrm{NH}_{3}$ (Kurtén et al., 2008) and can therefore enhance even more neutral and ion-induced $\mathrm{H}_{2} \mathrm{SO}_{4} / \mathrm{H}_{2} \mathrm{O}$ nucleation in the atmosphere. Bzdek et al. (2010) found experimental evidence for this effect: even at pptv-levels, complete displacement of $\mathrm{NH}_{3}$ by dimethylamine (DMA) occurs within seconds or minutes, changing the composition of sub-3 nm diameter bisulphate clusters. Not only substitution, but also addition to those clusters can occur, influencing their growth rates (Bzdek et al., 2011). Mäkelä et al. (2001) found that DMA was present at higher mixing ratios during nucleation events in boreal forests compared to non-event periods, making it a potential nucleating species or a species increasing growth rates of freshly formed particles, so that they can be detected faster at $3 \mathrm{~nm}$. Yu et al. (2012) also reported enhancement effects on the nucleation rate by several amines.

CLOUD4 (June-July 2011) investigated the role of DMA in the formation and growth of new particles. Because DMA needed to be detected at trace concentration levels, an ion 
chromatography (IC) method was deployed together with the sampling line developed for CLOUD by Bianchi et al. (2012). IC is often used to analyse amines and inorganic cations like ammonium $\left(\mathrm{NH}_{4}^{+}\right)$from atmospheric samples with various sampling methods (Mäkelä et al., 2001; Murphy et al., 2007; VandenBoer et al., 2011). The overall sampling efficiency of the method used for CLOUD4 for the simultaneous measurement of DMA and $\mathrm{NH}_{3}$ is discussed thereafter and the mixing ratios of both species are reported.

\section{Experimental}

\subsection{CLOUD chamber}

The CLOUD chamber is a $26.1 \mathrm{~m}^{3}$ electropolished stainless steel cylinder. A more detailed description can be found in Voigtländer et al. (2012) and Kirkby et al. (2011). The fibreoptic UV system for $\mathrm{H}_{2} \mathrm{SO}_{4}$ production with negligible thermal effect is described in Kupc et al. (2011). Although the chamber temperature can vary from 183 to $313 \mathrm{~K}$, it was kept constant at $278 \mathrm{~K}( \pm 0.01 \mathrm{~K})$ with a relative humidity of $38 \%$ $( \pm 0.1 \%)$ during CLOUD4.

\subsection{Sampling of $\mathrm{NH}_{3}$ and DMA}

The same sampling probe as the one described in Bianchi et al. (2012) was used (Fig. 1). It was specially designed to minimise the loss of $\mathrm{NH}_{3}$ and amines on surfaces. Briefly, it consists of a 2-mm diameter stainless steel tubing of $140 \mathrm{~cm}$ length with a small orifice to the CLOUD chamber. Ultra pure water $(18.2 \mathrm{M} \Omega \mathrm{cm})$ was introduced by a peristaltic pump in the stainless steel tubing $\left(0.25-0.80 \mathrm{ml} \mathrm{min}^{-1}\right)$. A cation trap column (CTC-2, Dionex) was additionally used to remove the possibly interfering cations from this water prior to sampling. As the water reached the orifice to the CLOUD chamber, it was mixed with air $\left(0.8-2.11 \mathrm{~min}^{-1}\right)$ in a 10-loop coil to allow for dissolution of the gaseous species into the water. With this setup only a section of $5 \mathrm{~mm}$ tubing remained unflushed by water, so that sampling losses became negligible.

A debubbler separates the air and the water, which is pumped from the bottom of the debubbler by a peristaltic pump. This water was passed through a trace cation concentrator column (TCC-2 or TCC-LP1, Dionex) where cations were retained. After 70 to $210 \mathrm{~min}$ of sampling, the 10-port valve described in Fig. 2 rotated to allow the elution of the cations to the analytical column, while the sampling water was concentrated on a second cation concentrator column to ensure continuous measurements. This automation was necessary as the CLOUD chamber cannot be accessed at all times (e.g. when it is irradiated by the pion beam) and it reduced the required maintenance to a minimum. No derivatisation was needed and the samples could be directly eluted to the analytical column automatically at the end of the sampling period.
To test the sampling efficiency for $\mathrm{NH}_{3}$ and amines, a second scrubbing system was installed in series at the end of the campaign as shown in the lower part of Fig. 1. It consisted of a Teflon ${ }^{\circledR}$ tubing of $1 \mathrm{~mm}$ diameter and $140 \mathrm{~cm}$ length. The air flow used for this setup was $11 \mathrm{~min}^{-1}$ and both liquid flows were $0.5 \mathrm{ml} \mathrm{min}^{-1}$. The sampling was alternated from one debubbler to the other using the valve system described previously.

\subsection{Ion chromatography (IC)}

A Dionex DX600 system was used for the analysis of the collected cations with Ionpac ${ }^{\circledR}$ CG10 and Ionpac ${ }^{\circledR}$ CS10 (Dionex) guard and analytical columns, respectively. The method used was similar to the one described in Chang et al. (2003): samples were eluted with $40 \mathrm{mM}$ methanesulfonic acid (MSA) at $1 \mathrm{ml} \mathrm{min}^{-1}$ (isocratic). Retention times varied between 8.8 and 10.5 min for $\mathrm{NH}_{3}$ and between 17.8 and $21.1 \mathrm{~min}$ for DMA. The peaks obtained from the conductivity detector were integrated manually. Calibration was performed by direct injection of aqueous standards (no preconcentration) of different concentration levels, corresponding to injected amounts ranging from 0 to $30 \mathrm{ng}$ for $\mathrm{NH}_{3}$ and 0 to $150 \mathrm{ng}$ for DMA (Fig. 3).

The method detection limit (MDL) depends primarily on the noise of the chromatograms, but is influenced by the sample volume (based on sampling air flow and sampling time). Depending on instrumental conditions and sampling time, the MDL ranged from 0.2 to $3.7 \mathrm{pptv}$ for $\mathrm{NH}_{3}$ and from 0.2 to $1.0 \mathrm{pptv}$ for DMA (signal $/$ noise $=3$ ).

\section{Results and discussion}

\subsection{Overall sampling efficiency and corrections}

The use of pure water without addition of an acidic compound is assumed to be sufficient for measurements of low mixing ratios of $\mathrm{NH}_{3}$ and DMA ( $<100$ pptv). From a theoretical point of view, the overall sampling efficiency relies on

- the efficiency of the concentrator columns,

- the stripping efficiency of the sampling device, and

- the protonation degree of $\mathrm{NH}_{3}$ and DMA, because these species are detected as cations.

Because the calibration by direct injection does not take into account the efficiency of the concentrator column,

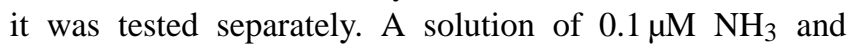
$0.1 \mu \mathrm{M}$ DMA was sampled on the concentrator columns. From the measured signals, a concentration of $0.055 \mu \mathrm{M}$ was calculated for both compounds, independent of the sampling time and the sampling flow. Therefore, a correction factor of 1.8 is applied to the mixing ratio of $\mathrm{NH}_{3}$ and DMA. Note 


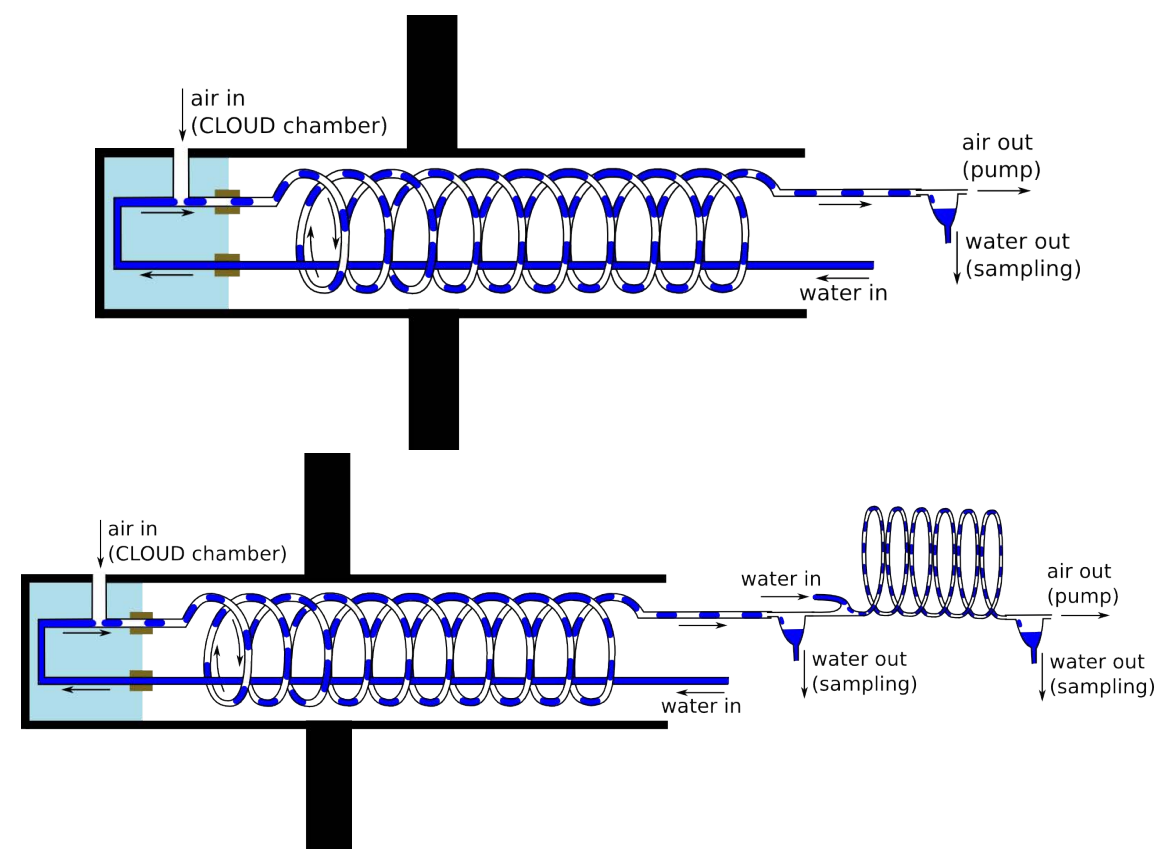

Fig. 1. Unscaled schematic of the sampling system used for CLOUD4 (top panel) and the modified sampling system with two debubblers (bottom panel) for sampling efficiency tests.
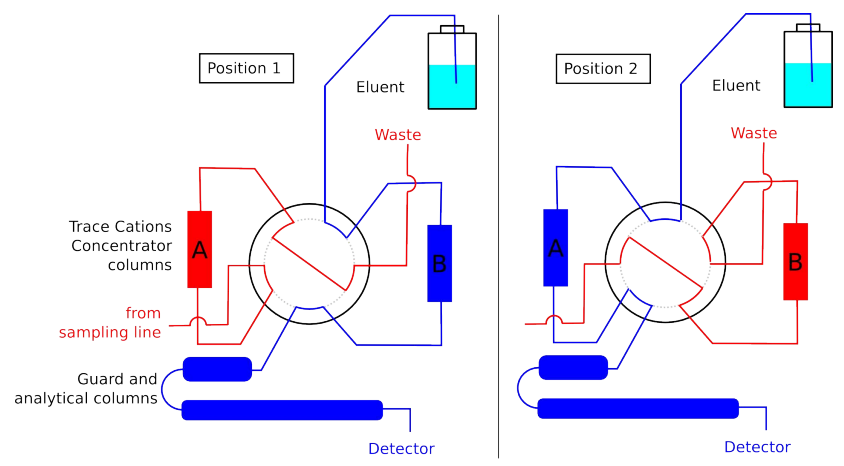

Fig. 2. Schematic of the concentrating system with two columns and a 10-port valve to ensure continuous measurements. While one column concentrates the analytes coming from the chamber sampling line (red line), the other column can be eluted and the sample analysed by ion chromatography (blue line).

that this effect is not due to the capacity of the concentrator column.

Indeed, the concentrator column capacity was found to be sufficient at those low levels and sampling with ultra pure water at less than $1 \mathrm{ml} \mathrm{min}^{-1}$ for a long period of time. However, due to this long sampling time, breakthrough of the analyte can happen. A sample was acquired for roughly $10 \mathrm{~h}$ (13-14 July) and the DMA mixing ratio derived (0.86 pptv) was consistent with the previous $(1.0 \mathrm{pptv}, 3.51 \mathrm{~h})$ and the following $(0.59 \mathrm{pptv}, 4.10 \mathrm{~h})$ samples (within uncertainties). For $\mathrm{NH}_{3}$, data from 14 and 15 July suggest that up to $4.5 \mathrm{~h}$ sampling time, the results (11 pptv, corrected) remains con- sistent with data acquired for 3.5 hours $(9.5$ and 13 pptv, also corrected). Therefore, for the sampling time of 210 minutes $(3.5 \mathrm{~h})$, no breakthrough of the analytes through the concentrator columns can be observed. A few $\mathrm{NH}_{3}$ mixing ratio values for sampling times longer than 4.5 hours were discarded.

The stripping efficiency relies on the effective Henry's law constant, $H^{*}$, which depends on the degree of protonation of the species in solution and thus on $\mathrm{pH}\left(-\log \left[\mathrm{H}^{+}\right]\right)$. Equation (1) defines $H^{*}$, taking into account the $\mathrm{pH}$ of the solution and the dissociation constant, $K_{\mathrm{a}}$, of the analytes. The negative logarithm of the dissociation constant $\left(\mathrm{p} K_{\mathrm{a}}\right)$ of $\mathrm{NH}_{4}^{+}$is 9.90 at $278 \mathrm{~K}$ (Bates and Pinching, 1950) and for dimethylaminium $\left(\mathrm{DMAH}^{+}\right.$) it is 10.64 at $293 \mathrm{~K}$ (Hall, 1957).

$H^{*}=H\left(1+10^{-\mathrm{pH}+\mathrm{p} K_{\mathrm{a}}}\right)=\frac{[\mathrm{B}]+\left[\mathrm{BH}^{+}\right]}{p_{\mathrm{B}}}$

where $p_{\mathrm{B}}$ is the partial pressure of base (B) in the gas phase. From the review of Sander (1999), Henry's law constants at $278 \mathrm{~K}$ are estimated to be in the range of $14.3-173 \mathrm{M} \mathrm{atm}^{-1}$ for $\mathrm{NH}_{3}$ and $81.3-150 \mathrm{M} \mathrm{atm}^{-1}$ for DMA. At this temperature, Hawkes (1995) reports a negative logarithm of the selfionisation constant of water $\left(\mathrm{p} K_{\mathrm{w}}=-\log \left(\left[\mathrm{H}^{+}\right]\left[\mathrm{OH}^{-}\right]\right)\right)$of 14.7, corresponding to a $\mathrm{pH}$ of 7.3 for pure water $\left(\mathrm{H}_{2} \mathrm{SO}_{4}\right.$ can be neglected). This value can increase up to 7.5 by dissolving low gas phase concentrations of DMA and $\mathrm{NH}_{3}(<100 \mathrm{pptv}$ each), assuming complete dissolution. Considering pure solutions of each species, the amount remaining in the gas phase $\left(p_{\mathrm{B}}\right)$ is between 0.24 and $2.8 \%$ for $\mathrm{NH}_{3}$ and between 


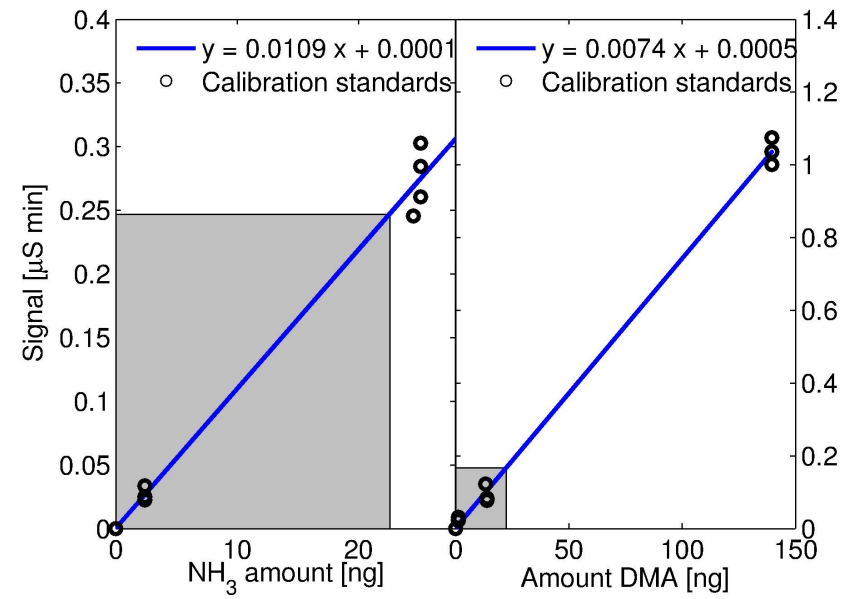

Fig. 3. Calibration plots for ammonia $\left(\mathrm{NH}_{3}\right.$, left panel) and dimethylamine (DMA, right panel). Grey areas correspond to the range of experimental data.

0.08 and $0.04 \%$ for DMA, assuming a liquid to air flow ratio of $0.3 \times 10^{-3}$.

This ratio influences the sampling efficiency as depicted in Fig. 4. The value of the ratio throughout the experiment is presented on the left, while the normalised signals obtained by varying the liquid to air flow ratio for a constant DMA mixing ratio in the chamber (around $100 \mathrm{pptv}$ ) are depicted on the right. If the liquid to air flow ratio drops below $0.3 \times 10^{-3}$, the sampling efficiency decreases indicating that the stripping efficiency is governed by the residence time and not the gas-liquid equilibrium. DMA mixing ratios were corrected for this observation (see Sect. 3.3).

Because $\mathrm{NH}_{3}$ was not injected at a constant mixing ratio into the chamber, the same test could not be done during CLOUD4, but has been previously made by Bianchi et al. (2012).

Moreover, the degree of protonation of both species in solution is higher than $99 \%$ (Eq. 2) at $\mathrm{pH} 7.5$ :

$$
\frac{[\mathrm{B}]}{\left[\mathrm{BH}^{+}\right]}=10^{\mathrm{pH}-\mathrm{p} K_{\mathrm{a}}} \text {. }
$$

Therefore, [B] can be neglected in Eq. (1) and because $p_{\mathrm{B}}$ is equal to the difference between the total amount of $\mathrm{B}$ in the system (here $100 \mathrm{pptv}$ ) and $\left[\mathrm{BH}^{+}\right], p_{\mathrm{B}}$ and $\left[\mathrm{BH}^{+}\right]$can be derived from Eq. (1).

Furthermore, at the end of the CLOUD4 campaign, a second sampling system was set in series with the first one as shown in the lower part of Fig. 1. No DMA could be detected in the water sampled from the second system, confirming the high overall sampling efficiency. Unfortunately, the second system was contaminated with $\mathrm{NH}_{3}$, so that no reliable conclusion can be drawn for this species.
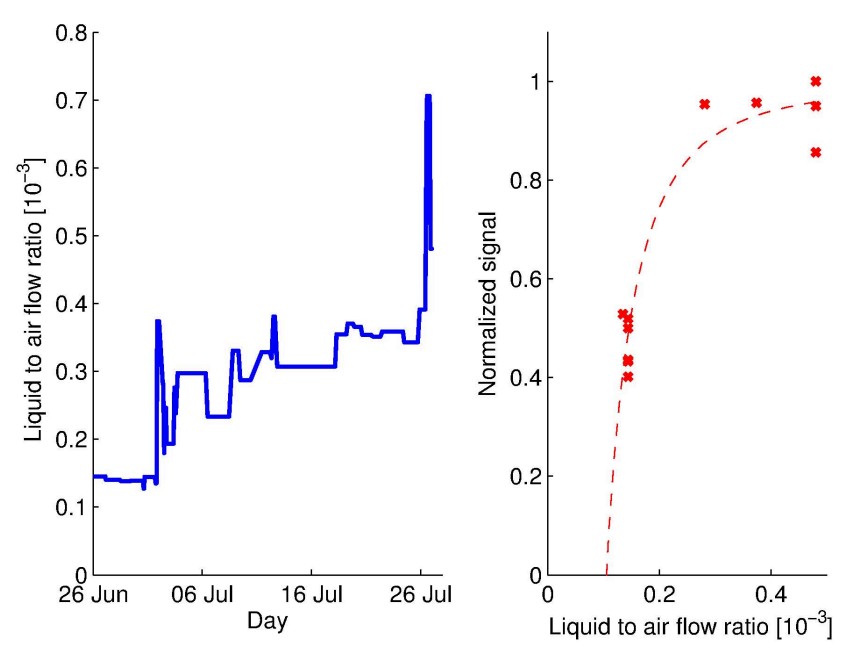

Fig. 4. Liquid to air flow ratio from the sampling line used during the campaign (left panel). Normalised signal varying the liquid to air flow ratio while sampling a constant DMA concentration (around $100 \mathrm{pptv}$ ) in the chamber (right panel) with fit curve $\left(y=a x^{b}+c\right)$.

\subsection{IC method}

The use of the CS10 analytical column from Dionex allowed the separation of $\mathrm{NH}_{3}$ and DMA without the two peaks interfering with each other, even when both species had very different concentration levels, which can often be problematic (VandenBoer et al., 2011). This was possible because of the cleanliness of the CLOUD chamber and the absence of interfering peaks. Only sodium and potassium peaks appeared in the chromatograms and were usually well resolved from the peaks of interest. However, during the period between 29 June and 7 July, due to an instrumental contamination with sodium, its high and broad peak sometimes masked the small $\mathrm{NH}_{4}^{+}$peak and increased the conductivity background during this period.

\section{3 $\mathrm{NH}_{3}$ and DMA mixing ratios}

Figures 5 and 6 summarise the measured mixing ratios for $\mathrm{NH}_{3}$ and DMA determined with IC. The instrument was not used at the very beginning of the campaign and no reliable data could be acquired between 6 and 11 July, due to an elevated conductivity background, which increased the MDL.

Blank values were obtained by directly sampling water instead of flushing it through the sampling line. No peak for DMA could be observed from these measurements during the whole campaign, so that no correction was applied to the obtained mixing ratio. On the other hand, $\mathrm{NH}_{3}$ showed peaks in the blank samples during the second phase of the campaign (after 11 July, when the sampling time was extended) and the measured mixing ratios were corrected proportionally to the water amount concentrated on the column (which depends on water flow and sampling time) for this period. 


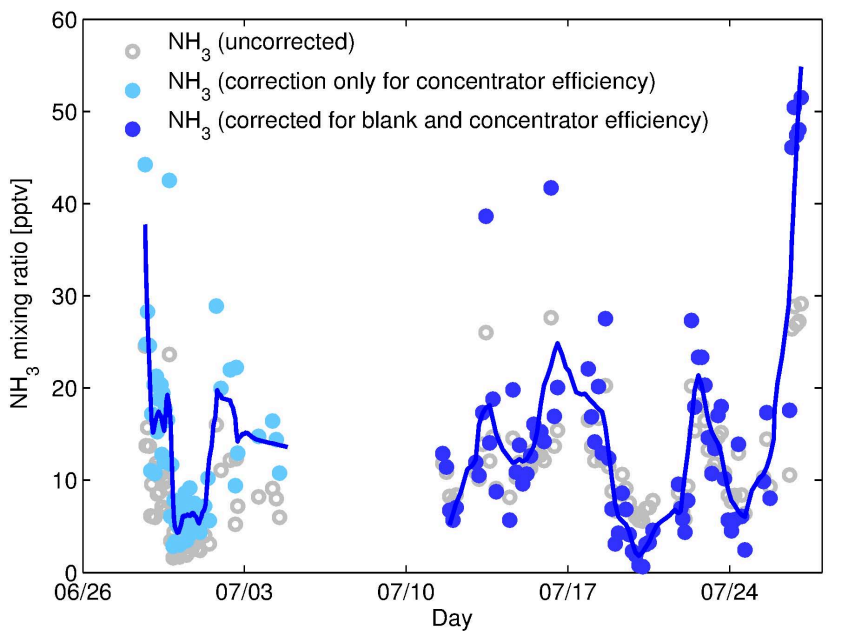

Fig. 5. Overview of ammonia $\left(\mathrm{NH}_{3}\right)$ mixing ratios (in pptv): uncorrected (grey), corrected only for concentrator column efficiency (filled light blue), and corrected for background levels as well as concentrator columns efficiency (filled dark blue). The continuous line is a smoothing function through the final data.

Figure 5 shows the uncorrected mixing ratios of $\mathrm{NH}_{3}$, as well as the ones corrected for efficiency of the concentrator column. In addition, background levels from the sampling water were substracted for the measurement period after 11 July. The $\mathrm{NH}_{3}$ mixing ratio ranged mostly below $25 \mathrm{pptv}$, which corresponds to mixing ratios found at remote locations (Krupa, 2003). This corresponds to the background level of $\mathrm{NH}_{3}$ in the CLOUD chamber at the present conditions.

The top panel of Fig. 6 shows the mass flow controller settings for continuous DMA injection into the CLOUD chamber. It was expected that the DMA levels were proportional to these settings. Indeed, the mixing ratios shown on the bottom panel of Fig. 6 followed this trend. However, after switching back from higher settings to lower ones, the measured mixing ratio did not drop to previous levels but showed a background of a few pptv, slowly decreasing. Data were multiplied by a correction factor derived from the fit curve of Fig. 4 and by the factor 1.8 to take the concentrator column efficiency into account.

The values reported for both species were in some cases very close to the MDL, in particular in the period from 21 to 24 July. With the sampling system used, no separation of the gas and aerosol phase occurred. For total aerosol mass loadings higher than $1 \mu \mathrm{g} \mathrm{m}^{-3}$, corrections may need to be considered, to take into account the ammonium and dimethylaminium from the particle phase.

DMA mixing ratios correspond to atmospherically relevant levels away from the sources (Ge et al., 2011). On the other hand, $\mathrm{NH}_{3}$ atmospheric levels range from a few hundreds of pptv to several ppbv (Li et al., 2006; Benson et al., 2010). Lower values could usually not be reported because of detection limitations.

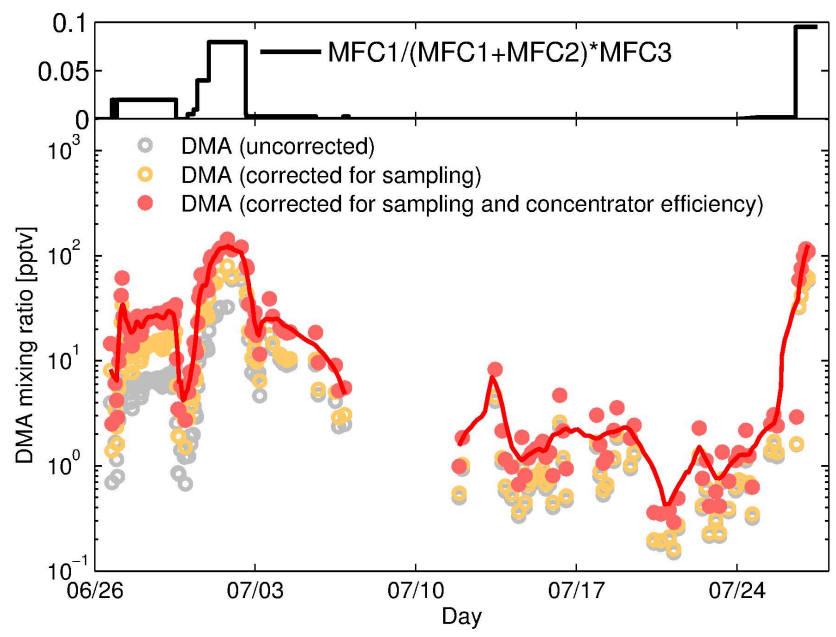

Fig. 6. Mass flow controllers (MFC) settings (top panel) and summary of dimethylamine (DMA) mixing ratio (in pptv) measured (lower panel): uncorrected (grey), corrected for sampling efficiency (orange), and corrected for sampling efficiency and concentrator column efficiency (filled red). The continuous line is a smoothing function through the final data. A logarithmic scale was used to visualise the data of the second half of the campaign (around 1 pptv).

\section{Conclusions and outlook}

The analysis of trace gases at pptv-level (ca. $10^{7} \mathrm{~cm}^{-3}$ ) is crucial for the understanding of nucleation because such levels of certain contaminants (e.g. $\mathrm{NH}_{3}$, organics) can be sufficient to enhance nucleation rates by several orders of magnitude. The method presented here, based on IC and making use of an efficient sampling line, could provide data down to sub-pptv levels with 70 to 210 min time resolution.

Studies at low temperature also need to be performed. However, for CLOUD campaigns below $273 \mathrm{~K}$, the sampling line needs to be adapted so that water does not freeze in the sampling line.

Grönberg et al. (1992) reported 0.5 and 1.8 pptv of DMA in urban and rural environments in Sweden. Chang et al. (2003) measured a broader range and slightly higher mixing ratios of DMA (1.9-34 pptv) at a suburban site in Seoul, Korea. Closer to agricultural sources, Schade and Crutzen (1995) found outdoor mixing ratios of DMA of $21 \mathrm{pptv}$ in the afternoon and 76 pptv just before sunrise. The levels of DMA injected into the CLOUD chamber represented well that range. Moreover, in all those studies, methylamine and trimethylamine were also present at similar levels (low pptv levels to a few hundreds of pptv). Akyüz (2007) found DMA levels of approximately $10 \mathrm{pptv}$, without a large variation between summer and winter, in six sampling sites in the Zonguldak province, Turkey, as well as strongly varying concentrations of various other amines.

Usually, $\mathrm{NH}_{3}$ is also present at several orders of magnitude higher levels (ppbv) than the individual amines. 
VandenBoer et al. (2011) reported amines to $\mathrm{NH}_{3}$ ratios in Toronto between $1.6-20 \times 10^{-3}$, while this ratio ranged from $9.4 \times 10^{-3}$ to 23 during the CLOUD4 campaign. The influence of such a level of DMA on nucleation and growth rates in the presence of a low $\mathrm{NH}_{3}$ mixing ratio will be the subject of other publications.

Acknowledgements. This work was supported by the Swiss National Science Foundation (project nos. 200020_135307 and 206620_130527) and by the EC Seventh Framework project CLOUD-ITN (MC-Initial Training Network No. 215072).

Edited by: V.-M. Kerminen

\section{References}

Akyüz, M.: Simultaneous determination of aliphatic and aromatic amines in indoor and outdoor air samples by gas chromatography-mass spectrometry, Talanta, 71, 486-492, doi:10.1016/j.talanta.2006.10.028, 2007.

Bates, R. G. and Pinching, G. D.: Dissociation constant of aqueous ammonia at 0 to $50^{\circ}$ from e.m.f. studies of the ammonium salt of a weak acid, J. Am. Chem. Soc., 72, 1393-1396, doi:10.1021/ja01159a087, 1950.

Benson, D. R., Markovich, A., Al-Refai, M., and Lee, S.-H.: A chemical ionization mass spectrometer for ambient measurements of ammonia, Atmos. Meas. Tech., 3, 1075-1087, doi:10.5194/amt-3-1075-2010, 2010.

Bianchi, F., Dommen, J., Mathot, S., and Baltensperger, U.: Online determination of ammonia at low pptv mixing ratios in the CLOUD chamber, Atmos. Meas. Tech., 5, 1719-1725, doi:10.5194/amt-5-1719-2012, 2012.

Bzdek, B. R., Ridge, D. P., and Johnston, M. V.: Size-dependent reactions of ammonium bisulfate clusters with dimethylamine, J. Phys. Chem. A, 114, 11638-11644, doi:10.1021/jp106363m, 2010.

Bzdek, B. R., Ridge, D. P., and Johnston, M. V.: Amine reactivity with charged sulfuric acid clusters, Atmos. Chem. Phys., 11, 8735-8743, doi:10.5194/acp-11-8735-2011, 2011.

Chang, I.-H., Lee, C.-G., and Lee, D. S.: Development of an automated method for simultaneous determination of low molecular weight aliphatic amines and ammonia in ambient air by diffusion scrubber coupled to ion chromatography, Anal. Chem., 75, 6141-6146, doi:10.1021/ac0347314, 2003.

Coffman, D. J. and Hegg, D. A.: A preliminary study of the effect of ammonia on particle nucleation in the marine boundary layer, J. Geophys. Res., 100, 7147-7160, doi:10.1029/94JD03253, 1995.

Ge, X., Wexler, A. S., and Clegg, S. L.: Atmospheric amines - Part I, A review, Atmos. Environ., 45, 524-546, doi:10.1016/j.atmosenv.2010.10.012, 2011.

Grönberg, L., Lövkvist, P., and Jönsson, J.: Determination of aliphatic amines in air by membrane enrichment directly coupled to a gas chromatograph, Chromatographia, 33, 77-82, doi:10.1007/BF02276856, 1992.

Hall, H. K.: Correlation of the base strengths of amines, J. Am. Chem. Soc., 79, 5441-5444, doi:10.1021/ja01577a030, 1957.
Hawkes, S. J.: $\mathrm{p} K_{\mathrm{W}}$ is almost never 14.0: Contribution from the task force on the General Chemistry Curriculum, J. Chem. Educ., 72, p. 799, 1995.

Hirsikko, A., Nieminen, T., Gagné, S., Lehtipalo, K., Manninen, H. E., Ehn, M., Hõrrak, U., Kerminen, V.-M., Laakso, L., McMurry, P. H., Mirme, A., Mirme, S., Petäjä, T., Tammet, H., Vakkari, V., Vana, M., and Kulmala, M.: Atmospheric ions and nucleation: a review of observations, Atmos. Chem. Phys., 11, 767798, doi:10.5194/acp-11-767-2011, 2011.

Kirkby, J.: Cosmic rays and climate, Surv. Geophys., 28, 333-375, doi:10.1007/s10712-008-9030-6, 2007.

Kirkby, J., Curtius, J., Almeida, J., Dunne, E., Duplissy, J., Ehrhart, S., Franchin, A., Gagné, S., Ickes, L., Kürten, A., Kupc, A., Metzger, A., Riccobono, F., Rondo, L., Schobesberger, S., Tsagkogeorgas, G., Wimmer, D., Amorim, A., Bianchi, F., Breitenlechner, M., David, A., Dommen, J., Downard, A., Ehn, M., Flagan, R. C., Haider, S., Hansel, A., Hauser, D., Jud, W., Junninen, H., Kreissl, F., Kvashin, A., Laaksonen, A., Lehtipalo, K., Lima, J., Lovejoy, E. R., Makhmutov, V., Mathot, S., Mikkilä, J., Minginette, P., Mogo, S., Nieminen, T., Onnela, A., Pereira, P., Petäjä, T., Schnitzhofer, R., Seinfeld, J. H., Sipilä, M., Stozhkov, Y., Stratmann, F., Tomé, A., Vanhanen, J., Viisanen, Y., Vrtala, A., Wagner, P. E., Walther, H., Weingartner, E., Wex, H., Winkler, P. M., Carslaw, K. S., Worsnop, D. R., Baltensperger, U., and Kulmala, M.: Role of sulphuric acid, ammonia and galactic cosmic rays in atmospheric aerosol nucleation, Nature, 476, 429-433, doi:10.1038/nature10343, 2011.

Korhonen, P., Kulmala, M., Laaksonen, A., Viisanen, Y., McGraw, R., and Seinfeld, J. H.: Ternary nucleation of $\mathrm{H}_{2} \mathrm{SO}_{4}, \mathrm{NH}_{3}$, and $\mathrm{H}_{2} \mathrm{O}$ in the atmosphere, J. Geophys. Res., 104, 26349-26353, doi:10.1029/1999JD900784, 1999.

Krupa, S. V.: Effects of atmospheric ammonia $\left(\mathrm{NH}_{3}\right)$ on terrestrial vegetation: a review, Environ. Pollut., 124, 179-221, doi:10.1016/S0269-7491(02)00434-7, 2003.

Kulmala, M., Pirjola, L., and Mäkelä, J. M.: Stable sulphate clusters as a source of new atmospheric particles, Nature, 404, 66-69, doi:10.1038/35003550, 2000.

Kulmala, M., Vehkamäki, H., Petäjä, T., Dal Maso, M., Lauri, A., Kerminen, V.-M., Birmili, W., and McMurry, P. H.: Formation and growth rates of ultrafine atmospheric particles: a review of observations, J. Aerosol Sci., 35, 143-176, doi:10.1016/j.jaerosci.2003.10.003, 2004.

Kupc, A., Amorim, A., Curtius, J., Danielczok, A., Duplissy, J., Ehrhart, S., Walther, H., Ickes, L., Kirkby, J., Kürten, A., Lima, J. M., Mathot, S., Minginette, P., Onnela, A., Rondo, L., and Wagner, P. E.: A fibre-optic UV system for $\mathrm{H}_{2} \mathrm{SO}_{4}$ production in aerosol chambers causing minimal thermal effects, J. Aerosol Sci., 42, 532-543, doi:10.1016/j.jaerosci.2011.05.001, 2011.

Kurtén, T., Loukonen, V., Vehkamäki, H., and Kulmala, M.: Amines are likely to enhance neutral and ion-induced sulfuric acid-water nucleation in the atmosphere more effectively than ammonia, Atmos. Chem. Phys., 8, 4095-4103, doi:10.5194/acp-8-4095-2008, 2008.

Li, Y., Schwab, J. J., and Demerjian, K. L.: Measurements of ambient ammonia using a tunable diode laser absorption spectrometer: Characteristics of ambient ammonia emissions in an urban area of New York City, J. Geophys. Res., 111, D10S02, doi:10.1029/2005JD006275, 2006. 
Mäkelä, J. M., Yli-koivisto, S., Hiltunen, V., Seidl, W., Swietlicki, E., Teinilä, K., Sillanpää, M., Koponen, I. K., Paatero, J., Rosman, K., and Hämeri, K.: Chemical composition of aerosol during particle formation events in boreal forest, Tellus B, 53, 380393, doi:10.1034/j.1600-0889.2001.530405.x, 2001.

Murphy, S. M., Sorooshian, A., Kroll, J. H., Ng, N. L., Chhabra, P., Tong, C., Surratt, J. D., Knipping, E., Flagan, R. C., and Seinfeld, J. H.: Secondary aerosol formation from atmospheric reactions of aliphatic amines, Atmos. Chem. Phys., 7, 2313-2337, doi:10.5194/acp-7-2313-2007, 2007.

Sander, R.: Compilation of Henry's law constants for inorganic and organic species of potential importance in environmental chemistry (Version 3), available at: http://www.henrys-law.org (15 June 2012), 1999.

Schade, G. W. and Crutzen, P. J.: Emission of aliphatic amines from animal husbandry and their reactions: Potential source of $\mathrm{N}_{2} \mathrm{O}$ and HCN, J. Atmos. Chem., 22, 319-346, doi:10.1007/BF00696641, 1995.
Tuazon, E. C., Atkinson, R., Aschmann, S. M., and Arey, J.: Kinetics and products of the gas-phase reactions of $\mathrm{O}_{3}$ with amines and related compounds, Res. Chem. Intermed., 20, 303-320, doi:10.1163/156856794X00351, 1994.

VandenBoer, T. C., Petroff, A., Markovic, M. Z., and Murphy, J. G.: Size distribution of alkyl amines in continental particulate matter and their online detection in the gas and particle phase, Atmos. Chem. Phys., 11, 4319-4332, doi:10.5194/acp-11-43192011, 2011.

Voigtländer, J., Duplissy, J., Rondo, L., Kürten, A., and Stratmann, F.: Numerical simulations of mixing conditions and aerosol dynamics in the CERN CLOUD chamber, Atmos. Chem. Phys., 12, 2205-2214, doi:10.5194/acp-12-2205-2012, 2012.

Yu, H., McGraw, R., and Lee, S.-H.: Effects of amines on formation of sub-3 nm particles and their subsequent growth, Geophys. Res. Lett., 39, L02807, doi:10.1029/2011GL050099, 2012. 